\title{
Oxidative Dimerization of BHA in Saturated and Unsaturated Triglycerides at High Temperature
}

\author{
Tsuyoshi FUjITANI \\ Fukuyama Branch School, Faculty of Education, Hiroshima University \\ (Midorimachi, Fukuyama-shi, Hiroshima, $\overline{\mathbf{7}} 720$ )
}

\begin{abstract}
The oxidative decomposition of $t$-butylated hydroxyanisole (BHA) and formation of its dimers were investigated during the thermal oxidation of saturated and unsaturated triglycerides.

Glycerol trilinoleate, in which BHA had been dissolved, was oxidized by air at $150^{\circ} \mathrm{C}$ to obtain two oxidation products of BHA from the reaction mixture by extraction with acetonitrile and silicic acid column chromatography. They were identified as the diphenyl ether type dimer and biphenyl type dimer of BHA by ${ }^{1} \mathrm{H}-\mathrm{NMR}$ and mass spectroscopy. The isomers of the BHA dimer and BHA monomer in oxidized triglycerides were determined by HPLC, using LiChrosorb SI-60 as the stationary phase, hexane-diisopropyl ether mixture $(9: 1)$ as the mobile phase, and a UV monitor $(290 \mathrm{~nm})$.

Changes in the concentrations of BHA and its dimers during the thermal oxidation of glycerol trilaurate and glycerol trilinoleate were followed by HPLC. In glycerol trilaurate, BHA was oxidized to give its dimers. The total quantities of BHA and its monomer showed little decrease. It is thus apparent that BHA dimers undergo only slight oxidative decomposition in saturated triglyceride. A considerable decrease in BHA concentration was observed in glycerol trilinoleate, and the total quantities of BHA and its dimers were less within the time tested than those in glycerol trilaurate. In the saturated triglyceride, a diphenyl ether type dimer predominated, but in the unsaturated triglyceride, a biphenyl type dimer was larger, indicating reversal of relative composition.
\end{abstract}

\section{Introduction}

$t$-Butylated hydroxyanisole (BHA)* is an effective antioxidant and has been used for the inhibition of autoxidation of many chemical industry's products. On the antioxidative effect of BHA added to edible fats and oils, many investigators have presented experimental results.

It is well known that the compounds with phenolic hydroxyl group dimerize at an early stage of air oxidation, and that the dimers also have antioxidative activity. In the previous papers $^{1,2)}$, the author reported that the dimers in three types (a diphenyl ether type dimer and two isomers of biphenyl type dimers) were obtained from the thermal oxidation products of tocopherols in triglycerides.

Thus far several reports have been presented on the dimers of BHA. Rosenwald and Chenicek ${ }^{3)}$ predicted the formation of a biphenyl type dimer as an oxidation product of BHA. It was shown by Kurechi and Senda ${ }^{4), 5}$ that two types of dimers were separated from photo-oxidized products of * 2-t-Butyl-4-methoxyphenol
BHA. Ishikawa and $\mathrm{Yuki}^{6}$ reported that a biphenyl type dimer of BHA was obtained from the reaction mixture of $\mathrm{BHA}$ and trimethylamine oxide in liquid paraffin at high temperature. The formation of BHA dimers was also reported in an autoclaved aqueous solution of $\mathrm{BHA}^{7)}$ and in a heated salad oil containing $\mathrm{BHA}^{8}$. However, few investigations have been made on the formation of BHA dimers in fats and oils at high temperature. Accordingly, it is of interest to clarify the oxidative dimerization of BHA in synthetic triglycerides, as a model of the oxidative dimerization of BHA in fats and oils.

In the present work, BHA was oxidized by air in synthetic triglycerides at high temperature, and two BHA dimers were separated from the reaction mixture. In addition, the time course of the amounts of BHA and its dimers during the thermal oxidation in saturated and unsaturated triglycerides were examined.

\section{Materials and Methods}

\subsection{Materials}

Commercially available reagent grade $\mathrm{BHA}$ 
was repeatedly recrystallized from hexane.

Glycerol trilaurate (Tri-La) (Tokyo Kasei) was used as saturated triglyceride without further purification. Glycerol trilinoleate (Tri-Li), used as unsaturated triglyceride, was synthesized from linoleic acid (Tokyo Kasei) and glycerol, and was purified by silicic acid column chromatography before use.

\subsection{Analytical methods}

NMR and mass spectra. ${ }^{1} \mathrm{H}-\mathrm{NMR}$ spectra were measured at $90 \mathrm{MHz}$ on a Hitachi K-22 spectrometer using tetramethylsilane as an internal standard. Field desorption mass spectra were obtained on a JOEL DX-300 mass spectrometer for the measurement of molecular weight.

TLC. Thin-layer plate (thickness, $0.25 \mathrm{~mm}$ ) prepared with Kieselgel $\mathrm{HF}_{254}$ and benzene as developping solvent were used. Chromatograms were visuarized with Emmerie-Engel's reagent.

HPLC. A Hitachi 655 model liquid chromatograph equipped with a variable wave length UV monitor was used. Peak retention times and areas were determined with a Hitachi 833 data processor. Silica gel (Merck LiChrosorb SI-60, $5 \mu \mathrm{m})$, which was packed in a stainless steel column $(4 \mathrm{~mm} \times 250 \mathrm{~mm})$, was used as a stationary phase. Hexane-diisopropyl ether $(9: 1) \mathrm{mix}$ ture was used as a mobile phase, at the flow rate of $1 \mathrm{~mL} / \mathrm{min}$. The compounds in the effluent were detected with UV monitor at $290 \mathrm{~nm}$. The concentration of each compound was calculated from peak area.

Carbonyl value. Carbonyl value of oxidized triglyceride was obtained by the official method of Japan Oil Chemists' Society.

\subsection{Isolation of Oxidation Products of BHA}

For the isolation and identification of oxidation products, Tri-Li, in which BHA was dissolved in the concentration of $10 \%$, was oxidized by air at $150^{\circ} \mathrm{C}$ for $7 \mathrm{~h}$ without stirring. Specific surface area was $0.7 \mathrm{~cm}^{2} / \mathrm{g}$. Reaction mixture was diluted with hexane and extracted with acetonitrile for three times. The acetonitrile layer was repeatedly washed with hexane. After acetonitrile had been distilled away, the oxidation products of BHA were separated by the chromatography on a silicic acid column eluted with hexane-diethyl ether mixture.

\subsection{Time Course of the Amounts of BHA and Its Dimers during Thermel Oxidation of Triglyceride}

Triglycerides containing $5 \%$ of BHA were oxidized by air without stirring in an oil bath controlled at $150^{\circ} \mathrm{C}$ or $180^{\circ} \mathrm{C}$ for a fixed time. Specific surface area was $0.5 \mathrm{~cm}^{2} / \mathrm{g}$. After the reaction mixture had been diluted with hexane to $0.05 \mathrm{~g} / \mathrm{mL}$, an aliquot of the solution was applied on HPLC for quantitation of BHA monomer and its dimers.

\section{Results and Discussion}

\subsection{Isolation and Identification of BHA Dimers}

On TLC of the acetonitrile extract of the reaction mixture obtained by air oxidation of BHA in Tri-Li, two spots appeared in addition to the spot of unreacted BHA; $R_{f}$ values were 0.84 for product $\mathrm{A}$, and 0.74 for product $\mathrm{B}$ ( $R_{f}$ value of BHA monomer, 0.42 ). These oxidation products were isolated from the extract by silicic acid elution chromatography. Product A is pale yellow oily substance and soluble in hexane. The analytical data of product $\mathrm{A}$ are as follows : MS $(m / z): 358\left(\mathrm{M}^{+}\right),{ }^{1} \mathrm{H}-\mathrm{NMR}(\delta): 1.42(18 \mathrm{H}, \mathrm{s}$, $t-\mathrm{Bu}), \quad 3.62\left(3 \mathrm{H}, \mathrm{s}, \mathrm{OCH}_{3}\right), 3.78(3 \mathrm{H}, \mathrm{s}$, $\left.\mathrm{OCH}_{3}\right), 5.60(1 \mathrm{H}, \mathrm{s}, \mathrm{Ar}-\mathrm{OH}), 6.20(1 \mathrm{H}, \mathrm{d}, \mathrm{Ar}-$ $\mathrm{H}), 6.60(1 \mathrm{H}, \mathrm{d}, \mathrm{Ar}-\mathrm{H}), 6.70(2 \mathrm{H}, \mathrm{d}, \mathrm{Ar}-\mathrm{H})$, 6. $96(1 \mathrm{H}, \mathrm{d}, \mathrm{Ar}-\mathrm{H})$. Product $\mathrm{B}$ is white crystalline. It is slightly soluble in hexane but soluble in hexane-diisopropyl ether mixture $(9: 1)$. The analytical data of product $\mathrm{B}$ are as follows: MS $(\mathrm{m} / z), 358\left(\mathrm{M}^{+}\right),{ }^{1} \mathrm{H}-\mathrm{NMR}(\delta): 1.42(18 \mathrm{H}, \mathrm{s}, t$ $-\mathrm{Bu}), 3.75\left(6 \mathrm{H}, \mathrm{s}, \mathrm{OCH}_{3}\right), 5.35(2 \mathrm{H}, \mathrm{s}, \mathrm{Ar}-$ $\mathrm{OH}), 6.65(2 \mathrm{H}, \mathrm{d}, \mathrm{Ar}-\mathrm{H}), 6.97(2 \mathrm{H}, \mathrm{d}, \mathrm{Ar}-\mathrm{H})$. From these spectral data, products $\mathrm{A}$ and $\mathrm{B}$ were identified as 6-t-butyl-2-(2-t-butyl-4-methoxyphenoxy)-4-methoxyphenol (BHA-ED) and 3, 3' -di-t-butyl-2, 2'-dihydroxy-5, 5'-dimethoxybiphenyl (BHA-BD), respectively.

From a number of observations concerning the inhibition of lipid oxidation by antioxidants, it has been well known that the inhibitory effect of phenolic antioxidants is based on the function as a chain stopper for the free radical chain reaction of lipid oxidation by the donation of hydrogen atom to peroxy radical generated from unsaturated fatty acid residue of triglycerides. Accordingly, a phenoxy type radical of BHA generates by remov- 
al of hydrogen atom from hydroxyl group in the molecule, and a part of this radical will be rearranged into a phenyl type radical. Therefore, BHA is believed to be dimerized as in the case of $\gamma$-tocopherol ${ }^{\prime \prime}$. The pathway was illustrated in Scheme-1.

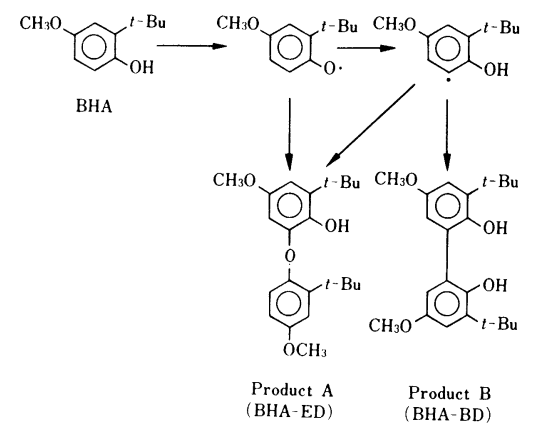

Scheme-1 Pathway of oxidative dimerization of BHA.

\subsection{Oxidative Dimerization of BHA in Satu- rated Triglycerides}

The changes of the concentrations of BHA and its dimers were followed during the course of thermal oxidation of Tri-La. Samples were taken out at regular time intervals and the amounts of unreacted BHA and its dimers formed in a reaction mixture were determined. The typical chromatogram of BHA, BHA-ED, and BHA-BD in a reaction mixture is shown in Fig.-1. Peaks

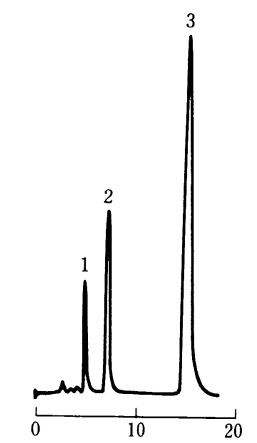

$$
\longrightarrow \text { Retention time }(\min )
$$

Peaks 1,2 and 3 correspond to BHA-ED,

$\mathrm{BHA}-\mathrm{BD}$ and BHA monomer.

Operating conditions:

Stationary phase, LiChrosorb SI-60,

$4 \mathrm{~mm} \times 250 \mathrm{~mm}$

Mobile phase, Hexane-diisopropyl ether 9:1 $1 \mathrm{~mL} / \min$ Detection, $290 \mathrm{~nm}$

Fig.-1 A high-performance liquid chromatogram of $\mathrm{BHA}$ and its dimers in a reaction mixture. were qualitatively identified by comparing the relative retention times with those of the reference standard compounds run under the same conditions.

In Figs.-2 and 3, the concentrations of BHA and its dimers in a reaction mixture are plotted against reaction time. From the data given in these figures, the following facts are clarified. The linear decrease of BHA concentration with respect to reaction time was observed, but the rate of decrease was very slow. About $80 \%$ of BHA remained in Tri-La even after the oxidation at $150^{\circ} \mathrm{C}$ for $20 \mathrm{~h}$. BHA was found to be considerably stable in saturated triglyceride at high temperature. The concentrations of BHA-ED and BHA-BD increased with the passage of time, and the amount of BHA-ED formed was about three times that of BHA-BD. This fact shows that the phenoxy type radical of BHA is more stable in

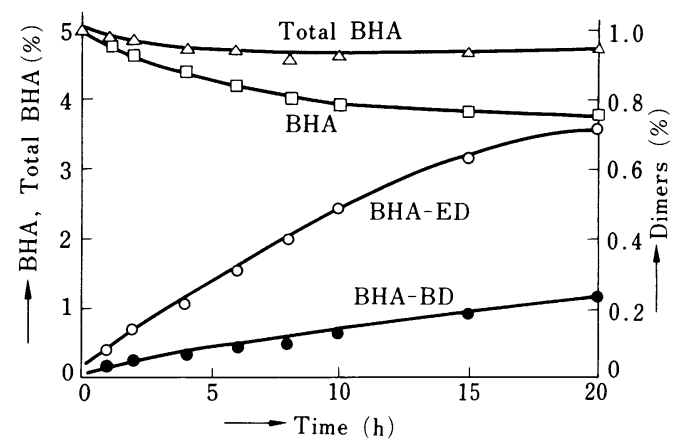

Total BHA : BHA monomer +BHA-ED+BHA-BD

Fig.-2 Changes in the concentrations of BHA and its dimers during thermal oxidation in glycerol trilaurate at $150^{\circ} \mathrm{C}$

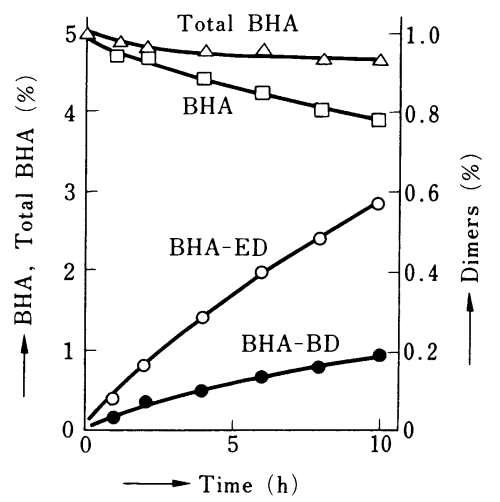

Fig.-3 Changes in the concentrations of BHA and its dimers during thermal oxidation in glycerol trilaurate at $180^{\circ} \mathrm{C}$. 
saturated triglyceride as compared with the phenyl type radical.

The total quantity of unreacted BHA and the dimers formed (Total BHA) showed little change during the period of thermal oxidation. This fact apparently indicates that BHA was oxidized to give the dimers and their further oxidation scarcely occurred under this condition. Erkilla et al. ${ }^{10}$ stated that BHA decomposes thermally at $130^{\circ} \mathrm{C}$ in inert silicone oil. On the other hand, White ${ }^{11}$ stated that the decrease of BHA concentration by thermal treatment is due to the volatility of BHA. From the author's results, it becomes clear that the loss of BHA during thermal oxidation results from the formation of the dimers and that the loss of BHA caused by its volatility is very small.

\subsection{Oxidative Dimerization of BHA in Un- saturated Triglyceride}

BHA was oxidized in Tri-Li in the same manner as in Tri-La. The results are shown in Figs. -4 and 5. After the oxidation at $150^{\circ} \mathrm{C}$ for

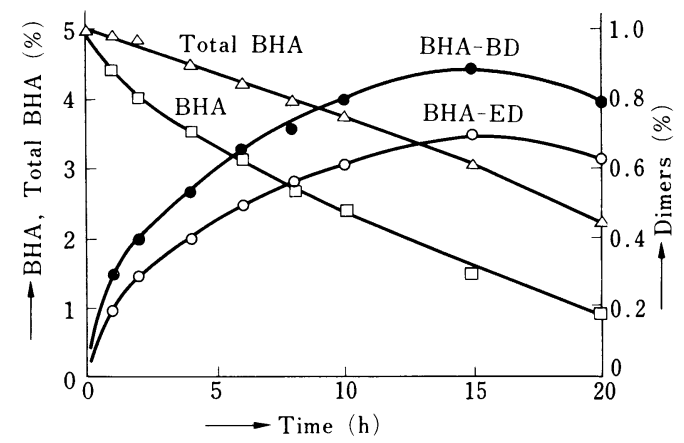

Fig.-4 Changes in the concentrations of BHA and its dimers during thermal oxidation in glycerol trilinoleate at $150^{\circ} \mathrm{C}$.

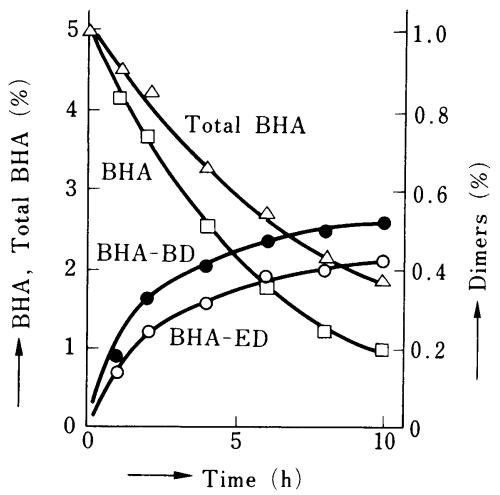

Fig. -5 Changes in the concentrations of BHA and its dimers during thermal oxidation in glycerol trilinoleate at $180^{\circ} \mathrm{C}$.
$20 \mathrm{~h}$, about $80 \%$ of BHA decomposed. The concentrations of the dimers increased as the oxidation time becomes longer, reached maximum at $15 \mathrm{~h}$, and then decreased slowly. On the oxidation in Tri-Li, BHA-BD was formed in larger quantities than BHA-ED. From this fact, it is concluded that the rearrangement of phenoxy type radical into phenyl type radical in $\mathrm{Tri}-\mathrm{Li}$ is more rapid than in Tri-La.

When $\mathrm{BHA}$ was oxidized at $180^{\circ} \mathrm{C}$, the decomposition rate of $\mathrm{BHA}$ increased about two times that at $150^{\circ} \mathrm{C}$, and the amount of the dimers formed at $180^{\circ} \mathrm{C}$ was smaller than that at $150^{\circ} \mathrm{C}$. The remarkable decrease of BHA concentration in unsaturated triglyceride was believed to be due to the hydrogen donation from a hydroxyl group of BHA to the free radicals generated from unsaturated fatty acid residue and the formation of the dimers by the recombination of two radicals derived from BHA. The dimers then decomposed to further oxidized compounds in unsaturated triglyceride, in contrast to the oxidation in saturated triglyceride, in which only the dimerization occurred. From these facts, it can be considered that the dimers are not necessarily stable on the oxidation in unsaturated triglyceride.

\section{$3 \cdot 4$ Oxidation of triglycerides}

Fig. -6 shows the change in carbonyl values of oxidized triglycerides. Large quantities of carbonyl compounds were formed by oxidation of Tri-Li even in the presence of a large amount of BHA. This fact suggests that BHA doesn't prevent the thermal oxidation of unsaturated triglycerides.

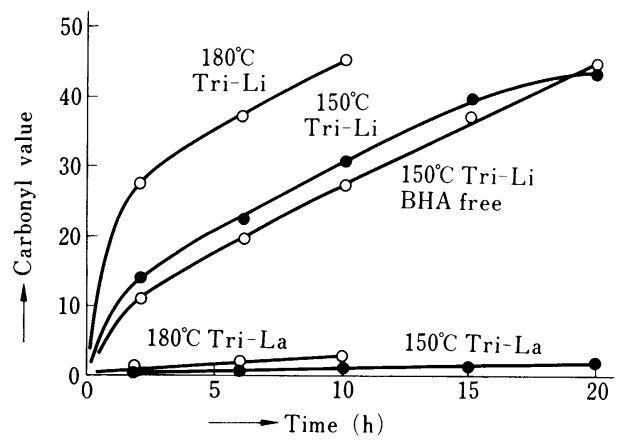

Fig.-6 Change in carbonyl value of triglycerides containing $5 \%$ of BHA during thermal oxidation. 


\section{Acknowledgement}

The author is grateful to Prof. M. Nakayama at University of Osaka Prefecture for the NMR spectra, to Prof. S. Oka at Hiroshima University for mass spectra, and to Mrs. H. Ando for technical assistance.

(Received April 2, 1987)

\section{References}

1) T. Fujitani and H. Ando, J. Jpn. Oil Chem. Soc. (Yukagaku), 26, 768 (1977).

2) T. Fujitani and H. Ando, J. Jpn. Oil Chem. Soc. (Yukagaku), 28, 896 (1979).

3) R. H. Rosenwald and J. A. Chenicek, J. Am. Oil Chem. Soc., 28, 185 (1951).

4) T. Kurechi, Eisei Kagaku, 13, 191 (1967).

5) T. Kurechi and S. Senda, Eisei Kagaku, 23, 267 (1977).

6) Y. Ishikawa and E. Yuki, Agr. Biol. Chem., 38, 1227 (1974).

7) W. C. Monte and J. A. Maga, J. Food Sci., 38, 898 (1973).

8) T. Ishitani, T. Hirata, J. Takai, and S. Kimura, Nippon Shokuhin Kogyo Gakkaishi, 23, 244 (1976).

9) Y. Ishikawa, J. Am. Oil Chem. Soc., 59, 505 (1982).

10) I. Erkilla, T. Fung, M. Kandiah, J. Wilkins, J. J. Moran, and J. A. Blake, J. Am. Oil Chem. Soc. , 55, 303 (1978).
11) P. A. White, J. Am. Oil Chem. Soc., 55, 739 (1978).

高温における飽和及び不飽和トリグリ

セリド中の BHA の酸化的二量化

\section{藤谷健 \\ 広島大学教育学部福山分校（}

飽和及び不飽和トリグリセリドの熱酸化中に起こる BHA の酸化的分解と二量体の生成について研究した。

BHA を溶かしたトリリノレインを $150^{\circ} \mathrm{C} て ゙$ 空気酸化 し, 反応混合物からアセトニトリルによる抽出とケイ酸 カラムクロマトグラフィーによって，2 種の BHA 酸化 生成物を得た。これらは, 'H-NMR とマススペトクル によって, BHA のジフェニルエーテル型二量体及びビ フェニル型二量体と同定した。トリラウリン及びトリリ ノレインの熱酸化に伴うBHA の減少と二量体の生成 を, HPLCによって追跡した。その結果, トリラウリ ン中における酸化においては，BHA は二量体まで酸化 されそれ以上の酸化はほとんど起こらなかった。また， 生成する二量体はジフェニルエーテル型の方が多かっ た。これに対してトリリノレイン中における酸化では, BHA は速い速度で酸化し, 二量体を経て更に酸化分解 し, また, 生成する二量体はビフェニル型二量体の方が 多く生成した。

\section{国際油脂情報}

えカノーラ油のアメリカへの輸入量增大

〔INFO 1号 (1988) 吉富和彦]

アメリカへのカナダからカノーラ油の輸入量は, 1986/87 年には 6 万 9,000トンに増大したと Canola Digest 紙が報じている。1984/85 年には 1 万 1,000トン，1985/86 年には 3 万 3,000トンの輸入量であった。同紙は アメリカ健康財団が，P\& G 社のピュリタン・ブランド油（100％カノーラ油）を，昨年における推奨商品 に選んだことを報じている。

\section{えソ連の油糧種子生産, 詳細わかる}

ソ連における 1985 年と 1986 年の公的な油糧種子搾油処理明細が,ソヴィエト新聞紙上に発表された。公的デー 夕が発表されたのは，アメリカの観測筋によれば，初めてのことである。1986 年 (括弧内は1985 年) の搾油 原料処理量は次のとおり。ひまわり 367 万 6,200トン (331 万 6,400トン), 綿実 433 万 1,700トン (407万 5,100 トン), 大豆 179 万 4,600 トン (91 万 1,200トン), ひまし 5 万 500 トン ( 5 万 4,900 トン), からし 5 万 2,000 トン $(4$ 万 2,200 トン), あまに 1 万 9,700 トン $(2$ 万 3, 500 トン),なたね 4 万 6,500 トン $(1$ 万 6,300 ト ン)，その他を含め合計 1,009 万 3,600 トン ( 853 万 6,300 トン) となっている。 